\title{
Phenotypic Variability of Krabbe Disease Across the Lifespan
}

\author{
Pamela Liao, Jennifer Gelinas, Sandra Sirrs
}

\begin{abstract}
Krabbe disease (galactocerebrosidase deficiency) is an inherited leukodystrophy that results in severe neurological defects due to altered myelination. Classically, disease onset is within the first year of life. Juvenile and adult-onset cases may have less classic presentations, making diagnosis difficult and often delayed. Here, we review the literature to demonstrate the hetereogeneity of presenting symptoms across all age groups. We also discuss diagnostic approach, emphasizing variation in biochemical, functional, and genetic results among Krabbe phenotypes. Better understanding of the various Krabbe disease phenotypes is critical to facilitate timely diagnosis and appropriate treatment of this clinically heterogeneous disorder.
\end{abstract}

\begin{abstract}
RÉSUMÉ: Variabilité phénotypique dans la maladie de Krabbe au cours de la vie du patient. La maladie de Krabbe (déficit en galactocérébrosidase) est une leukodystrophie héréditaire qui donne lieu à des déficits neurologiques sévères dus à un trouble de la myélinisation. Chez les cas dont la présentation est classique, la maladie débute au cours de la première année de vie. Si la maladie commence chez un adolescent ou un adulte, le mode de présentation peut-être moins classique, ce qui rend le diagnostic difficile et souvent tardif. Nous analysons les articles traitant du sujet pour démontrer l'hétérogénéité des symptômes au moment de la première consultation et ceci dans tous les groupes d'âge. Nous discutons également de l'approche diagnostique en mettant l'emphase sur la variation des résultats biochimiques, fonctionnels et génétiques des différents phénotypes dans la maladie de Krabbe. Une meilleure compréhension des différents phénotypes est cruciale pour faciliter un diagnostic précoce et un traitement approprié de cette maladie dont le mode de présentation clinique est hétérogène.
\end{abstract}

Can J Neurol Sci. 2014; 41: 5-12

\section{Epidemiology}

The incidence of Krabbe disease (OMIM \# 245200) is estimated to be one case for every 100,000 members of the population in the United States and Europe ${ }^{1}$. While there are a growing number of reported cases in adolescents and adults, population rates according to age of onset are not available. It affects the sexes equally and the carrier frequency in those with no family history is about one in $150^{1}$. There may be an increased incidence in certain Israeli populations ${ }^{2}$, where estimates of carrier prevalence are one in $\operatorname{six}^{1}$.

\section{Pathophysiology}

Krabbe disease (galactocerebrosidase deficiency, galactosylceramidase deficiency, globoid cell leukodystrophy) is an autosomal recessive neurological disorder. Mutations in the galactosylceramidase gene (GALC; galactocerebrosidase) result in the phenotype of Krabbe disease by means of abnormal accumulation of galactolipids, such as galactosylceramide and psychosine, predominantly in cells that make myelin (oligodendrocytes) $^{3}$. Macrophages containing undigested galactosylceramide can be observed as the pathognomonic globoid cells of Krabbe disease ${ }^{4}$. Pathologically, this metabolic disruption causes significantly decreased myelin production and demyelination due to depletion of oligodendroglia ${ }^{5,6}$.

Histopathological correlation with magnetic resonance imaging (MRI) white matter abnormalities reveals that absence of myelin is associated with areas of T2 hyperintensity, whereas perivascular accumulation of globoid cells can result in subtle, perivascularly oriented stripes of T2 hypointensity ${ }^{7}$.

\section{Phenotypic Variability}

The most recognized clinical presentation of Krabbe disease involves infantile onset of symptoms with rapid neurologic deterioration and progression to death before two years of age. However, there have been increasing reports of this disease presenting later in life, with substantial variability in presenting symptomatology and natural history (see Table 1 for summary). These phenotypes are less well characterized, leading to delays in diagnosis and treatment. The Krabbe patient population may be classified by age of onset into four different phenotypes:

From the Department of Obstetrics \& Gynaecology (PL), University of Toronto, Toronto, Ontario; Division of Pediatric Neurology (JG), Faculty of Medicine, Adult Metabolic Diseases (SS), University of British Columbia, Vancouver, British Columbia, Canada.

Received May 8, 2013. Final Revisions Submitted August 1, 2013. Correspondence to: Sandra Sirrs, Gordon and Leslie Diamond Centre, Adult Metabolic Diseases Clinic, 2775 Laurel St., Level 4, Vancouver, British Columbia, V5Z 1M9, Canada.Email: sandra.sirrs@vch.ca. 
Table 1: Relative prevalence of presenting symptoms in Krabbe disease phenotypes

\begin{tabular}{|c|c|c|c|c|}
\hline & \multicolumn{4}{|c|}{ Krabbe Disease Phenotypes } \\
\hline & $\begin{array}{c}\text { Early Infantile } \\
0-6 \text { months }\end{array}$ & $\begin{array}{c}\text { Late Infantile } \\
6 \text { months }-3 \text { years }\end{array}$ & $\begin{array}{c}\text { Juvenile } \\
3 \text { years }-8 \text { years }\end{array}$ & $\begin{array}{c}\text { Adult } \\
>8 \text { years }\end{array}$ \\
\hline \multicolumn{5}{|l|}{ Presenting Symptoms } \\
\hline Irritability & +++ & ++ & - & - \\
\hline Hyperpyrexia & +++ & - & - & - \\
\hline Loss of motor ability & +++ & +++ & ++ & ++ \\
\hline Spasticity & +++ & +++ & +++ & +++ \\
\hline Ataxia & - & +++ & +++ & +++ \\
\hline Visual dysfunction & + & +++ & +++ & + \\
\hline Seizures & ++ & + & - & - \\
\hline Cognitive deterioration & +++ & +++ & ++ & + \\
\hline
\end{tabular}

$(-)=$ uncommon $(+)=$ possible $(++)=$ likely $(+++)=$ highly likely

early-infantile (0 months - 6 months); late-infantile (6 months 3 years); juvenile (3 years -8 years); adult $(8+\text { years })^{1,8-10}$.

\section{Early-Infantile Phenotype}

\section{Presenting Symptoms}

The early-infantile phenotype, which constitutes $85-95 \%$ of Krabbe disease, ${ }^{1}$ demonstrates a clear sequence of progression. Children are initially developmentally normal but developmental delays typically appear before the age of six months ${ }^{11}$.

Stage one involves non-specific generalized symptoms including irritability, failure to thrive, vomiting, and hyperpyrexia. Subtle neurologic findings like shoulder girdle hypotonia and intermittent thumb clasp may be found ${ }^{12}$. Patients may show exaggerated startle responses due to auditory, tactile and visual hyperesthesia (increased sensitivity to sensory stimuli). Overall, the most common presenting symptoms described by families of early-infantile Krabbe disease are crying and irritability (90\%), stiffness (27\%), poor feeding $(27 \%)$, poor head control $(25 \%)$, seizures $(23 \%)$, fisting $(18 \%)$, and loss of smiling $(15 \%)^{13}$. These symptoms are generally attributable to central nervous system dysfunction. Although peripheral neuropathy can be demonstrated electrophysiologically at this stage $^{14}$, its manifestations (including weakness and hyporeflexia), are usually overshadowed by the more clinically apparent central nervous system dysfunction. Rarely, patients may present with profound muscular weakness, hypotonia, and areflexia indicative of isolated peripheral nerve dysfunction ${ }^{15}$.

Stage two is characterized by rapid clinical deterioration. Seizures are more common at this stage. Optic atrophy and slow pupillary light reflexes can occur. Other neurological findings include hypertonic flexion of the arms and extension of the legs, myoclonic jerks, hyper- or hyporeflexia, psychomotor deterioration, and point opisthotonus (spasm of back muscles causing trunk to arch forward) $)^{11,16}$.

Stage three is often referred to as the "burnt-out stage". Symptoms include blindness, deafness, decerebrate posturing, and loss of voluntary movement. The motor disability is attributable to a combination of pyramidal tract dysfunction and progressive peripheral neuropathy. Patients are unable to feed orally and typically require tube feeds ${ }^{11}$. End-stage morbidities include infection, respiratory failure, and feeding difficulties leading to emaciation ${ }^{1,16-18}$.

\section{Rate of Progression and Prognosis}

Median survival rates range from 8 to 36 months-of-age for early-infantile cases ${ }^{1,12,13}$. Generally, prognosis is much worse for early-infantile compared to late-infantile and juvenile subtypes $^{13}$.

\section{Late-Onset Infantile Phenotype}

\section{Presenting Symptoms}

The late-infantile phenotype involves patients with onset of symptoms between six months and three to four years of age ${ }^{8,16}$. Early development is typically normal and children initially meet their milestones. Initial symptoms are difficulty walking, frequent falling, and clumsiness ${ }^{10,19,20}$. Neurologic exam shows common presenting signs of spastic paraparesis $(54 \%)$, cerebellar ataxia $(12.5 \%)$, isolated vision failure $(12.5 \%)$, and isolated hemiplegia $(8 \%)^{20}$. These presenting complaints, which are predominantly in the gross motor domain, distinguish this phenotype from the early-infantile subgroup, which features irritability and lethargy as chief presenting complaints ${ }^{19}$. Some patients do present with seizures, although this is uncommon ${ }^{20}$.

\section{Advanced Symptoms}

The natural history of the late-infantile phenotype is progressive deterioration of motor function, mainly secondary to pyramidal tract dysfunction. Patients typically regress to crawling and some lose the ability to sit unsupported. Progressive motor dysfunction leads to quadriplegia. Peripheral neuropathy may be present, and contributes to motor disability ${ }^{19}$. Visual changes range from intact vision to complete blindness. Some patients develop seizures ${ }^{10}$. Many patients become nonverbal, but some maintain communication abilities through the use of computers and other aids ${ }^{10}$. Feeding difficulties and emaciation may also occur ${ }^{21}$.

\section{Rate of Progression and Prognosis}

Life expectancy is variable in this phenotype, ranging from 214 years after initial presentation (average is seven years) $)^{19,20,22}$. 
In comparison to the early-infantile groups, patients in the lateinfantile subtype have greater life expectancy, but with the burden of advanced disease ${ }^{13}$.

\section{Juvenile Onset Phenotype}

\section{Age Range}

Juvenile onset Krabbe disease, consisting of patients with symptom onset at three to eight years of age, has often been combined with the late-infantile form due to the relative rarity of these phenotypes. However, there is some evidence to suggest that this phenotype may have a different clinical course from earlier onset cases, with ramifications pertaining to prognosis and therapy ${ }^{23}$.

\section{Presenting Symptoms}

Visual dysfunction is a common initial presenting symptom in the juvenile-onset subtype ${ }^{24,25}$. Motor dysfunction, such as hemiparesis or ataxia, is still prominent ${ }^{19,22}$. Pes cavus, or high arched feet, is another symptom that has been reported to appear prior to diagnosis, and is indicative of peripheral neuropathy ${ }^{10}$.

There is wide phenotypic variability in this subgroup, suggesting that environmental factors interact significantly with genetic factors. This phenomenon is particularly evident in cases of siblings with juvenile onset Krabbe disease, who have similarly decreased GALC activity, but nevertheless exhibit dramatically different clinical courses ${ }^{24,26}$. For example, Phelps et $a l^{24}$ report the case of a young girl who presented with visual impairment at five years-of-age, and progressed to being wheelchair bound with dystonic movements and incomprehensible speech by 12 years-of-age. Assessment of her 16-year-old brother revealed history of mild walking difficulties in early childhood and non-progressive reduced visual acuity with normal intellect. Unfortunately, genetic mutation analysis was not reported in these two cases.

\section{Advanced Symptoms}

Visual deterioration to light perception only or complete blindness is common. Patients also typically develop spasticity, quadriplegia, and cerebellar ataxia; many patients become wheelchair-bound ${ }^{10}$. The course of intellectual decline is highly variable and ranges from intact intellectual ability to severe cognitive dysfunction $\left({ }^{24}\right.$, Case $1 ;{ }^{10}$ Cases 12,13$)$. Interestingly, the pace of decline in childhood may stabilize in adulthood ${ }^{25}$. Some patients retain verbal skills ${ }^{25}$, while others develop dysarthria $\left({ }^{24}\right.$, Case 3 ) or complete verbal loss $\left({ }^{10}\right.$, Case $5 ;{ }^{24}$, Case 1). End-stage disease may have swallowing difficulties leading to aspiration risk $\left({ }^{10}\right.$, Case 5$)$, although some patients remain cognitively high-functioning ${ }^{25}$.

\section{Rate of Progression and Prognosis}

Most juvenile cases show initial rapid deterioration in the first two to six months after onset of symptoms, followed by more gradual progression over years. Survival has been reported up to 26 years $\left({ }^{19}\right.$, Case 14$)$.

\section{Adult Onset Phenotype}

\section{Age Range}

The definition of adult onset Krabbe disease has posed interesting challenges. It has been suggested that this subgroup should further be split into two categories; those who are a) clinically normal until onset of symptoms at age 20 years, and b) those who may have presented earlier in life, but whose symptoms were so subtle that biochemical testing was not warranted until later in life ${ }^{1}$. Determination of whether patients with purported adult-onset Krabbe disease did have mild symptoms in childhood is difficult, as these patients may not have been previously formally assessed. As such, accurate generalized conclusions about this Krabbe disease phenotype are limited.

Like the juvenile subtype, there can be wide phenotypic variation within families. Verdru et $a l^{27}$ report a family with an index patient who presented with weakness at 19 years-of-age. Investigation into family history revealed one brother who developed clumsiness at 14 months, deteriorated to spasticity and blindness, and died at four years-of-age. As such, family members with presumably the same Krabbe genotype can manifest with either the late-infantile and adult phenotype.

\section{Presenting Symptoms}

Presenting symptoms include limb weakness (upper extremity may be more common than lower extremity), clumsiness, recurrent falls, and worsening gait ${ }^{9,28}$. Spasticity becomes prominent in the vast majority of patients, whereas manifestations of peripheral neuropathy are subtle (pes cavus or sensory abnormalities; significant neuropathic pain has not been reported $)^{29}$. Some patients are asymptomatic and identified through family screening.

\section{Advanced Symptoms}

Much like the presentation of these patients, clinical outcomes in this subtype are varied. Asymptomatic patients assessed due to a sibling's initial diagnosis tended to remain stable after several years follow-up $\left({ }^{24}\right.$, Case $4 ;{ }^{26}$, Case 2$)$, but siblings who presented with clinical symptoms tend to decline in a similar pattern $\left({ }^{30}\right.$ Cases 2 and 3$)$. Outcomes of adult patients who present with motor dysfunction tend to follow the same course as earlier onset subtypes, developing progressive weakness and spasticity that can culminate in quadriparesis. Verbal and cognitive decline can also become severe $\left({ }^{24}\right.$, Case 2$)$, although in some cases cognition is preserved $\left({ }^{9}\right.$, Case $\left.2 ;^{31}\right)$. Genitourinary symptoms reported include urinary incontinence and erectile dysfunction ${ }^{9}$.

\section{Rate of Progression and Prognosis}

The majority of patients progressed in terms of physical, and sometimes cognitive, dysfunction, but were alive up to 10-15 years after the initial onset of symptoms. In this adult-onset subgroup there have been attempts to perform bone marrow transplantation. Whereas two twin sisters subsequently succumbed to complications of graft vs. host disease ${ }^{10}$, there is one report of a 24-year-old woman who initially declined very rapidly, but was stabilized by bone marrow transplantation ${ }^{32}$. 
Table 2: Differential diagnoses of Krabbe disease phenotypes based on presenting symptoms

\begin{tabular}{|c|c|c|c|}
\hline Early Infantile $0-6$ months & Late Infantile 6 months -3 years & Juvenile 3 years -8 years & Adult $>8$ years \\
\hline \multicolumn{4}{|c|}{ Leukodystrophies } \\
\hline $\begin{array}{l}\text { Metachromatic leukodystrophy } \\
\text { Peroxisomal biogenesis defects } \\
\text { GM1 gangliosidosis } \\
\text { GM2 gangliosidosis } \\
\text { Canavan disease } \\
\text { Alexander disease } \\
\text { Pelizaeus-Merzbacher disease }\end{array}$ & $\begin{array}{l}\text { Metachromatic leukodystrophy } \\
\text { Adrenoleukodystrophy } \\
\text { GM2 gangliosidosis (juvenile) } \\
\text { Alexander disease } \\
\text { Pelizaeus-Merzbacher disease }\end{array}$ & $\begin{array}{l}\text { Metachromatic leukodystrophy } \\
\text { Adrenoleukodystrophy } \\
\text { GM2 gangliosidosis (juvenile) }\end{array}$ & $\begin{array}{l}\text { Metachromatic leukodystrophy } \\
\text { Adrenomyeloneuropathy } \\
\text { GM2 gangliosidosis (adult) }\end{array}$ \\
\hline \multicolumn{4}{|c|}{ Storage Disorders } \\
\hline $\begin{array}{l}\text { Mucopolysaccharidoses (type I, III) } \\
\text { Gaucher disease } \\
\text { Niemann Pick disease type A }\end{array}$ & $\begin{array}{l}\text { Mucopolysaccharidoses (type II, VII) } \\
\text { Gaucher disease } \\
\text { Niemann Pick disease type C }\end{array}$ & $\begin{array}{l}\text { Gaucher disease } \\
\text { Sialodosis type II } \\
\text { Niemann Pick disease type C }\end{array}$ & $\begin{array}{l}\text { Niemann Pick disease type C } \\
\text { Cerebrotendinous xanthomatosis }\end{array}$ \\
\hline \multicolumn{4}{|c|}{ Amino Acidopathies } \\
\hline \multirow{2}{*}{\multicolumn{4}{|c|}{$\begin{array}{l}\text { Maple syrup urine disease } \\
\text { Homocystinuria } \\
\text { Phenylketonuria }\end{array}$}} \\
\hline & & & \\
\hline $\begin{array}{l}\text { MELAS } \\
\text { Alpers disease } \\
\text { Leigh disease } \\
\text { Menkes syndrome }\end{array}$ & $\begin{array}{l}\text { MELAS } \\
\text { Alpers disease (late-onset) } \\
\text { Leigh disease } \\
\text { MERRF }\end{array}$ & $\begin{array}{l}\text { MELAS } \\
\text { MERRF } \\
\text { Leigh disease (juvenile) }\end{array}$ & $\begin{array}{l}\text { MELAS } \\
\text { MERRF }\end{array}$ \\
\hline \multicolumn{4}{|c|}{ Other Gray Matter Disorders } \\
\hline $\begin{array}{l}\text { Infantile ceroid lipofuscinosis } \\
\text { Lesch-Nyhan disease } \\
\text { Rett syndrome }\end{array}$ & Late-infantile ceroid lipofuscinosis & $\begin{array}{l}\text { Juvenile ceroid lipofuscinosis } \\
\text { Hereditary spastic paraparesis }\end{array}$ & $\begin{array}{l}\text { Adult ceroid lipofuscinosis } \\
\text { Motor neuron disease } \\
\text { Hereditary spastic paraparesis }\end{array}$ \\
\hline \multicolumn{4}{|c|}{ Other Myelin Disorders } \\
\hline & & Multiple sclerosis & $\begin{array}{l}\text { Multiple sclerosis } \\
\text { Charcot Marie Tooth (types 1,2) }\end{array}$ \\
\hline \multicolumn{4}{|c|}{$\begin{array}{l}\text { Infectious Disease } \\
\end{array}$} \\
\hline AIDS encephalopathy & $\begin{array}{l}\text { AIDS encephalopathy } \\
\text { Congenital syphilis } \\
\text { Subacute sclerosing panencephalitis }\end{array}$ & Subacute sclerosing panencephalitis & Syphilis \\
\hline
\end{tabular}

MERRF = Myoclonic Epilepsy with Ragged Red Fibers; MELAS = Mitochondrial Encephalomyopathy, Lactic Acidosis, and Stroke-like episodes.

Two brothers with onset at ages 41 and 45 years who were not transplanted died due to complications of respiratory failure ${ }^{30}$.

\section{Diagnosis}

Clinical diagnosis of Krabbe disease is challenging. Patients with early-infantile onset typically present with nonspecific symptoms, leading to delays in diagnosis up to three years after the onset of symptoms ${ }^{17}$. Of early-infantile cases with initial incorrect diagnoses $(n=28)$, family questionnaires have revealed that the most common misdiagnoses for Krabbe disease include cerebral palsy ${ }^{16}$, colic ${ }^{6}$, combined cerebral palsy and colic ${ }^{2,13}$. Patients with later onset disease have symptoms and signs that often overlap with other metabolic, toxic and genetic disorders. Common misdiagnoses in the adult-onset population include Charcot Marie Tooth syndrome, multiple sclerosis, mild cerebral palsy, and amyotrophic lateral sclerosis (see Table 2 for summary of key (not inclusive) differential diagnoses for Krabbe disease phenotypes). Although the presentation of individual patients may eliminate many of the diagnoses listed in Table 2 from consideration, the many documented atypical presentations of various neurodegenerative disorders (including Krabbe disease), generally merit an initially broad differential diagnosis. As a result, clinical suspicion of Krabbe disease must be supplemented with diagnostic investigations (see Table 3 for features differentiating Krabbe disease from key differential diagnoses). Once a white matter disorder is identified on neuroimaging, specific MRI characteristics have proven critical to narrowing the differential diagnosis ${ }^{33}$. However, diagnostic results can also be variable between the different Krabbe phenotypes, and some results carry potential prognostic significance (see Table 4 for summary of pertinent investigations and results in Krabbe phenotypes) $)^{1,3,9,14,19,28,34-44}$.

\section{Screening biochemistry}

Routine bloodwork in Krabbe disease is typically normal. Cerebrospinal fluid (CSF) protein can be elevated in all phenotypes, but does not correlate with disease progression ${ }^{12}$. Ninety-two percent of early-infantile onset patients in one report had elevated CSF protein at initial neurodiagnostic evaluation $(>25 \mathrm{mg} / \mathrm{dL} \text { above normative values for age })^{45}$ and specific values range from $65-400 \mathrm{mg} / \mathrm{dL}^{46}$. In contrast, approximately $50 \%$ of juvenile-onset and adult-onset cases reveal elevated CSF, with specific values ranging from $13-77 \mathrm{mg} / \mathrm{dL}$ in one study ${ }^{29}$.

\section{Functional Studies}

\section{Electromyography (EMG) and Nerve Conduction Studies (NCS)}

Electromyography studies in Krabbe patients typically reveal a pattern consistent with peripheral nerve damage ${ }^{3}$. Most early- 
Table 3: Features differentiating Krabbe disease from key differential diagnoses

\begin{tabular}{|c|c|c|c|c|c|c|c|}
\hline & $\begin{array}{l}\text { Possible Unique } \\
\text { Clinical Features }\end{array}$ & $\begin{array}{l}\text { CSF } \\
\text { Abnormalities }\end{array}$ & $\begin{array}{l}\text { Ophthalmologic } \\
\text { Abnormalities }\end{array}$ & $\begin{array}{l}\text { Nerve Conduction } \\
\text { Studies }\end{array}$ & Neuroimaging Findings & Biochemical Abnormality & $\begin{array}{l}\text { Genetic } \\
\text { Testing }\end{array}$ \\
\hline Krabbe disease & $\begin{array}{l}\text { Irritability (infantile } \\
\text { only) }\end{array}$ & Increased protein & Optic atrophy & $\begin{array}{l}\text { Demyelinating } \\
\text { pattern }\end{array}$ & $\begin{array}{l}++\mathrm{T} 2 \text { hyperintensity } \\
\text { (parieto-occipital } \\
\text { predominance) }\end{array}$ & $\begin{array}{l}\text { Galactocerebrosidase } \\
\text { deficiency }\end{array}$ & GALC $^{1}$ \\
\hline $\begin{array}{l}\text { Metachromatic } \\
\text { leukodystrophy }\end{array}$ & None & Increased protein & Optic atrophy & $\begin{array}{l}\text { Demyelinating } \\
\text { pattern }\end{array}$ & $\begin{array}{l}++\mathrm{T} 2 \text { hyperintensity } \\
\text { (periventricular } \\
\text { predominance) }\end{array}$ & Arylsulfatase A deficiency & $\mathrm{ARSA}^{2}$ \\
\hline GM2 gangliosidosis & $\begin{array}{l}\text { Myoclonus } \\
\text { Macrocephaly }\end{array}$ & Normal & Cherry red spot & Normal & Hypomyelination & $\begin{array}{l}\text { Hexosaminidase A } \\
\text { deficiency }\end{array}$ & $\mathrm{HEXA}^{3}$ \\
\hline Niemann Pick C & $\begin{array}{l}\text { Organomegaly } \\
\text { Vertical } \\
\text { supranuclear gaze } \\
\text { palsy }\end{array}$ & $\begin{array}{l}\text { Possible reduced } \\
\text { hypocretin }\end{array}$ & $\begin{array}{l}\text { Possible cherry } \\
\text { red spot }\end{array}$ & Typically normal & $\begin{array}{l}\text { Cerebellar vermis } \\
\text { atrophy } \\
\text { Possible T2 } \\
\text { hyperintensity } \\
\text { (periventricular } \\
\text { predominance) }\end{array}$ & $\begin{array}{l}\text { Abnormality of } \\
\text { intracellular cholesterol } \\
\text { homeostasis }\end{array}$ & $\mathrm{NPC} 1, \mathrm{NPC}^{4}$ \\
\hline $\begin{array}{l}\text { Mitochondrial } \\
\text { disease }\end{array}$ & $\begin{array}{l}\text { Diabetes } \\
\text { Cardiomyopathy }\end{array}$ & Increased lactate & $\begin{array}{l}\text { Retinitis } \\
\text { pigmentosa } \\
\text { Optic atrophy }\end{array}$ & Axonal pattern & $\begin{array}{l}\text { Variable } \\
\text { Possible cerebral or } \\
\text { cerebellar atrophy } \\
\text { Possible }++\mathrm{T} 2 \\
\text { hyperintensity of basal } \\
\text { ganglia or white matter }\end{array}$ & Increased serum lactate & Various \\
\hline $\begin{array}{l}\text { Hereditary spastic } \\
\text { paraparesis }\end{array}$ & Hypertonic bladder & Normal & Typically normal & Typically normal & $\begin{array}{l}\text { Possible corpus callosum } \\
\text { or cerebral atrophy }\end{array}$ & Normal & Various $\left(\mathrm{SPG}^{5}\right)$ \\
\hline
\end{tabular}

${ }^{1}$ galactocerebrosidase; ${ }^{2}$ arylsulfatase A; ${ }^{3}$ beta-hexosaminidase A; ${ }^{4}$ Niemann-Pick C; ${ }^{5}$ spastic gait loci. MERRF $=$ Myoclonic Epilepsy with Ragged Red Fibers; MELAS = Mitochondrial Encephalomyopathy, Lactic Acidosis, and Stroke-like episodes.

infantile onset cases have abnormal NCS (23/24 patients; sensitivity $>95 \%$ ) with disease severity correlating with degree of demyelination ${ }^{14}$. The combination of pyramidal tract dysfunction (spasticity, hyperreflexia) with electrophysiological evidence of demyelinating peripheral neuropathy is classical for Krabbe disease and substantially narrows the differential diagnosis of a neurodegenerative disorder. Clinical evidence of peripheral neuropathy is often only apparent late in disease course when NCS are severely abnormal (but see ${ }^{47}$ for rare exceptions). Importantly, NCS can be normal in later-onset patients, so the absence of abnormalities should not be used to exclude the disease ${ }^{1}$.

\section{Electroencephalography (EEG)}

Krabbe patients show a non-specific slowing of EEG background activity, with spikes generally absent ${ }^{3}$. While EEG may be normal at initial stages of the disease, progression of disease involves slowing and disorganization of background activity that may be asymmetric ${ }^{1}$. A greater percentage of earlyinfantile onset patients $(65 \%)$ may have abnormal EEGs compared to late onset cases $(33 \%)^{39}$. Correspondingly, seizures are more common in early-infantile onset patients ${ }^{48,49}$. Seizure semiology has not been well characterized, but myoclonic seizures have been reported ${ }^{48}$. Seizure activity is likely reflective of as yet poorly understood cortical involvement in Krabbe disease $^{6}$. However, it is difficult to eliminate a contribution from co-existent disease processes in some cases (for example, toxicity post-hematopoietic stem cell transplant, trauma, or obstructive hydrocephalus) ${ }^{50}$.

\section{Visual Evoked Potentials (VEP) and Brain-stem auditory Evoked Potentials (BAEP)}

Visual evoked potentials and brain-stem auditory evoked potentials in Krabbe disease may show nonspecific abnormalities more commonly in the earlier onset phenotypes. Brain-stem auditory evoked potentials may be one of the first diagnostic measures to become abnormal in Krabbe disease, as measured in pre-symptomatic genetically diagnosed patients ${ }^{40}$. VEPs and BAEPs may help to monitor disease progression, as abnormalities correlate with disease burden on neuroimaging ${ }^{39}$.

\section{Computed Tomography (CT)}

Brain CT can initially be normal or display hyperdensity in the posterior limb of the internal capsule, thalamus, and corona radiata $^{12,51}$. Over time, diffuse cerebral atrophy evolves, involving both gray and white matter ${ }^{1}$. Diffuse hypodensity of white matter may also be present, particularly in the parietooccipital regions. Interestingly, some evidence suggests that CT may show hyperdensities despite normal MRI ${ }^{1}$.

\section{Magnetic Resonance Imaging (MRI)}

Magnetic resonance imaging shows consistent changes of demyelination in periventricular white matter (prominent T2 hyperintensity and T1 hypointensity) with relative sparing of subcortical U-fibres ${ }^{43}$. Stripes of perivascularly oriented T2 hypointensities within abnormal white matter can be observed, a feature which is shared with metachromatic leukodystrophy and GM1 gangliosidosis ${ }^{7}$. Involvement of the pyramidal tract and posterior corpus callosum is characteristic for all phenotypes, but "early-onset" patients tend to have consistent abnormalities in the cerebellum and brainstem that may predate supratentorial 
Table 4: Comparison of diagnostic results in Krabbe disease phenotypes

\begin{tabular}{|c|c|c|c|c|c|}
\hline & \multicolumn{4}{|c|}{ Krabbe Disease Phenotypes } & \multirow[b]{2}{*}{ Reference(s) } \\
\hline & $\begin{array}{c}\text { Early Infantile } \\
0-6 \text { months }\end{array}$ & $\begin{array}{c}\text { Late Infantile } \\
6 \text { months }-3 \text { years }\end{array}$ & $\begin{array}{c}\text { Juvenile } \\
3 \text { years - } 8 \text { years }\end{array}$ & $\begin{aligned} & \text { Adult } \\
> & 8 \text { years }\end{aligned}$ & \\
\hline \multicolumn{5}{|c|}{ Diagnostic Results } & \\
\hline CSF protein & $\begin{array}{c}\text { Increased in }> \\
90 \%\end{array}$ & Increased in $>90 \%$ & $\begin{array}{c}\text { Increased in } \\
40-70 \%\end{array}$ & Increased in $50-75 \%$ & $(29,34)$ \\
\hline $\begin{array}{l}\text { GALC enzyme activity (\% of average } \\
\text { control values) }\end{array}$ & $0-5 \% *$ & $<15 \%$ & $<15 \%$ & $<15 \%$ & $(9,12,19,35)$ \\
\hline Common GALC mutations & $\begin{array}{c}\text { Large deletions } \\
1538 \mathrm{C}>\mathrm{T} \\
1652 \mathrm{~A}>\mathrm{C} \\
1954 \mathrm{~A}>\mathrm{C} \\
\end{array}$ & $\begin{array}{c}\text { G270D } \\
\text { G41S }\end{array}$ & $\begin{array}{c}\text { G270D } \\
\text { G41S }\end{array}$ & $\begin{array}{c}\text { G270D } \\
\text { G41S }\end{array}$ & $(36,37,38)$ \\
\hline $\begin{array}{l}\text { Abnormal NCS - mixed sensorimotor } \\
\text { demyelinating peripheral neuropathy }\end{array}$ & +++ & + & + & + & $\begin{array}{l}\text { Early-infantile: (14) } \\
\text { Late-onset: (1) }\end{array}$ \\
\hline $\begin{array}{l}\text { Abnormal VEP/BAEPs - non specific } \\
\text { changes, correlate with disease } \\
\text { progression }\end{array}$ & +++ & ++ & + & + & $(39,40)$ \\
\hline $\begin{array}{l}\text { Abnormal EEG - non-specific } \\
\text { slowing, absent spikes, }\end{array}$ & +++ & ++ & + & + & $(1,39)$ \\
\hline $\begin{array}{l}\text { Magnetic resonance spectroscopy } \\
\text { (MRS) - } \uparrow \text { choline } \downarrow \text { N- } \\
\text { acetylaspartate, and } \downarrow \text { glutamate }\end{array}$ & +++ & ++ & - & - & $(41,42,43)$ \\
\hline $\begin{array}{l}\text { Common localization of } \\
\text { neuroimaging abnormalities }\end{array}$ & $\begin{array}{l}\text { - cerebellum } \\
\text { - pyramidal tract } \\
\text { - parieto-occipital } \\
\text { white matter }\end{array}$ & $\begin{array}{l}\text { - pyramidal tract } \\
\text { - corpus callosum } \\
\text { - parieto-occipital } \\
\text { white matter }\end{array}$ & $\begin{array}{l}\text { - pyramidal tract } \\
\text { - corpus callosum } \\
\text { - parieto-occipital } \\
\text { white matter }\end{array}$ & $\begin{array}{c}\text { - normal } \\
\text { - pyramidal tract } \\
\text { - parieto-occipital } \\
\text { white matter }\end{array}$ & $(3,9,28,41,43,44)$ \\
\hline
\end{tabular}

$(-)=$ uncommon $(+)=$ possible $(++)=$ likely $(+++)=$ highly likely. $*$ activity up to $10 \%$ has been uncommonly reported ${ }^{35}$.

changes ${ }^{44}$. Gadolinium enhancement of cranial nerve roots and the cauda equina has also been noted in these "early-onset" patients only ${ }^{52}$. Another rarely reported "early-onset" feature is optic nerve enlargement, which may be due to globoid cell accumulation via poorly understood mechanisms ${ }^{53}$.

In contrast, MRI of adult-onset patients often reveals the first changes within proximal corticospinal tracts ${ }^{41}$, though imaging can be normal ${ }^{9,28}$. Notably, MRI can be normal or unchanged despite deterioriating clinical status regardless of phenotype ${ }^{54}$ so MRI cannot be used to exclude the diagnosis or definitively assess clinical progression ${ }^{9,28}$. A detailed description of the wide range of MRI findings possible in the various phenotypic presentations of Krabbe disease is beyond the scope of this review, but the reader is referred to several recent references included here ${ }^{41,55,56}$.

\section{Magnetic resonance spectroscopy (MRS)}

Magnetic resonance spectroscopy findings in Krabbe disease are variable, but include increased choline, decreased $\mathrm{N}$ acetylaspartate and decreased glutamate ${ }^{41-43}$. These abnormalities may initially be localized to areas of abnormal signal on MRI, but can be seen more diffusely with disease $\operatorname{progression}^{41,42}$.

\section{GALC Enzyme Activity}

Galactocerebrosidase enzyme activity is the preferred diagnostic test for patients suspected of having Krabbe disease, regardless of age of onset. There are some reports of lower levels of GALC enzyme activity in normal unaffected adults compared to similarly unaffected neonates ${ }^{57}$, suggesting that GALC activity may vary over lifespan although this finding is not consistent ${ }^{58}$. While enzyme activity $0-5 \%$ of reference values is diagnostic, levels have not been consistently linked to disease severity ${ }^{1,16,36}$. Enzyme activity is typically non-detectable in early-infantile subtypes ${ }^{35}$, while varying levels of residual activity have been reported in the other age groups (Table 3 ). Overall, further investigation is required to assess how GALC activity levels relate to various phenotypes of Krabbe disease and what quantitative levels should be used for diagnosis across the population.

\section{Genetic Analysis}

In addition to enzymatic analyses, analysis of mutations in the galactocerebrosidase (GALC) gene testing is useful. Over 110 different mutations in this gene have been described ${ }^{59}$, and some specific mutations seem to correlate loosely with age of disease onset and prognosis. Early-infantile forms in the European population are typically characterized by homozygosity for a $30 \mathrm{~kb}$ deletion that begins in intron 10 (IVS10del30kb; OMIM 606890.0002) (36 $^{36}$ are compound heterozygotes for this deletion and another severe deleterious allele $^{16}$. The overall allele frequency for this $30 \mathrm{~kb}$ deletion is estimated at $40-50 \%{ }^{36}$. In the Japanese population, early infantile forms are often typified by a different deletion ${ }^{37}$.

Later onset phenotypes are more commonly characterized by G286D (OMIM 606890.0008) or G41S (OMIM 606890.0010) mutations, regardless of the mutation contained in the second allele $36,37,59,60$. In fact, the G41S (OMIM 606890.0010) mutation has been reported in up to $50 \%$ late-onset cases in some populations ${ }^{38}$. Genetic mutation analysis may also inform 
phenotype-specific prognosis, as the G41S (OMIM 606890.0010) mutation is associated with longer survival in lateonset phenotypes only ${ }^{19}$. Genetic testing is used for confirmation of diagnosis, carrier testing (as GALC enzyme activity levels are unreliable), prenatal diagnosis, and genetic counselling ${ }^{1}$.

\section{Management}

Prior to the late 1990s, clinical treatment for Krabbe disease was mainly supportive. In patients of all phenotypes, key symptomatic treatments target spasticity, feeding difficulties and seizures, with the use of physical and occupational therapy to maximize functional outcome. Infantile-onset patients who display irritability (whether secondary to central or peripheral nervous system dysfunction) are treated to maximally reduce gastroesophageal reflux. Morphine has also been successfully used to control irritability ${ }^{53}$.

With the advent of hematopoietic stem cell transplantation (HSCT) as a potentially viable therapy, the importance of effectively diagnosing these patients and providing appropriate therapeutic and prognostic counselling has become more apparent. Most HSCT has taken place among pre-symptomatic infantile cases $^{23,32,61}$, and while no patients have died of progressive disease, all have abnormalities of gross motor control and expressive language. These patients also characteristically display poor growth and microcephaly ${ }^{49}$. Transplantation of juvenile- and adult-onset patients has been less frequent, although case reports suggest that these patients may derive benefit from the procedure as well ${ }^{32,62}$. Hematopoietic stem cell transplantation involves significant risk of morbidity and mortality, and does not entirely prevent disease progression.

\section{Conclusion And Future Directions}

Krabbe disease is a source of significant morbidity and mortality to those affected. Newborn screening for this disorder is being performed at select centres, allowing for improved understanding of its epidemiology and early identification of at risk patients. Importantly, early data derived from this screening suggests that the proportion of late-onset Krabbe disease has likely been under-estimated ${ }^{34}$. In parallel to these diagnostic efforts, the search for more effective and less invasive therapeutics for Krabbe disease continues. Although currently in pre-clinical stages, therapies involving pharmacologic chaperones to increase activity of mutant GALC enzyme ${ }^{63}$, viral vectors for gene therapy ${ }^{64}$ and neural progenitor cells injected into the $\mathrm{CNS}^{65}$ show promise. As Krabbe disease transitions to a potentially treatable disorder, clinicians will require understanding of its phenotypic variability to avoid misdiagnosis and allow for timely institution of therapy.

\section{ACKNOWLEDGMENT}

The authors thank Dr. Michelle Demos (Division of Pediatric Neurology, University of British Columbia) for additional clinical insight into the differential diagnosis of Krabbe disease.

\section{REFERENCES}

1. Wenger DA. Krabbe disease. In: Pagon RA, Bird TD, Dolan CR, editors. GeneReviews. Seattle, WA: University of Washington; 2008.
2. Zlotogora J, Regev R, Zeigler M, Iancu TC, Bach G. Krabbe disease: Increased incidence in a highly inbred community. Am J Med Genet. 1985;21(4):765-70.

3. Ropper AH, Samuels MA. Inherited metabolic diseases of the nervous system. In: Adam and Victor's Principles of Neurology. 9th Edition ed. USA: McGraw Hill; 2009.

4. Suzuki K. Globoid cell leukodystrophy (Krabbe's disease): Update. J Child Neurol. 2003;18(9):595-603.

5. Barranger JA, Cabrera-Salazar MA, Matsuda J, Suzuki K. Krabbe disease (Globoid Cell Leukodystrophy). In: Lysosomal Storage Disorders. Springer. New York, NY, US; 2007. p. 269-83.

6. Wenger DA, Suzuki K, Suzuki Y, Suzuki K. Galactosylceramide lipidosis: Globoid cell leukodystrophy (Krabbe disease). In: Scriver CR, Beaudet AL, Sly WS, Valle D, Vogelstein B, editors. Metabolic and Molecular Bases of Inherited Disease. New York, NY: McGraw-Hill; 2011.

7. van der Voorn JP, Pouwels PJ, Kamphorst W, et al. Histopathologic correlates of radial stripes on MR images in lysosomal storage disorders. AJNR Am J Neuroradiol. 2005;26(3):442-6.

8. Kemper AR, Knapp AA, Green NS, Comeau AM, Metterville DR, Perrin JM. Weighing the evidence for newborn screening for early-infantile Krabbe disease. Genet Med. 2010 ;12(9):539-43.

9. Bajaj NP, Waldman A, Orrell R, Wood NW, Bhatia KP. Familial adult onset of Krabbe's disease resembling hereditary spastic paraplegia with normal neuroimaging. J Neurol Neurosurg Psychiatry. 2002;72(5):635-8.

10. Kolodny EH, Raghavan S, Krivit W. Late-onset Krabbe disease (Globoid Cell Leukodystrophy): Clinical and biochemical features of 15 cases. Dev Neurosci. 1991;(4-5):232-9.

11. Hagberg B. Krabbe's disease: Clinical presentation of neurological variants. Neuropediatrics. 1984;15 Suppl:11-5.

12. Escolar ML, Poe MD, Martin HR, Kurtzberg J. A staging system for infantile Krabbe disease to predict outcome after unrelated umbilical cord blood transplantation. Pediatrics. 2006;118(3): e879-89.

13. Duffner PK, Jalal K, Carter RL. The Hunter's Hope Krabbe family database. Pediatr Neurol. 2009;40(1):13-18.

14. Siddiqi ZA, Sanders DB, Massey JM. Peripheral neuropathy in Krabbe disease: Electrodiagnostic findings. Neurology. 2006;67 (2):263-7.

15. Korn-Lubetzki I, Dor-Wollman T, Soffer D, Raas-Rothschild A, Hurvitz H, Nevo Y. Early peripheral nervous system manifestations of infantile Krabbe disease. Pediatr Neurol. 2003; 28(2):115-18.

16. Pastores GM. Krabbe disease: an overview. Int J Clin Pharmacol Ther. 2009;47 Suppl 1:S75-81.

17. Kohler W. Leukodystrophies with late disease onset: an update. Curr Opin Neurol. 2010;23(3):234-41.

18. Chabali R, Matre WM, Greene MK. Infant with irritability, feeding problems, and progressive developmental abnormalities presenting repeatedly to a pediatric emergency department. Pediatr Emerg Care. 1997;13(2):123-6.

19. Fiumara A, Barone R, Arena A, et al. Krabbe leukodystrophy in a selected population with high rate of late onset forms: longer survival linked to c. $121 \mathrm{G}>\mathrm{A}$ (p.Gly41Ser) mutation. Clin Genet. 2011; 80(5):452-8.

20. Lyon G, Hagberg B, Evrard P, Allaire C, Pavone L, Vanier M. Symptomatology of late onset Krabbe's leukodystrophy: the European experience. Dev Neurosci. 1991;13(4-5):240-4.

21. Barone R, Bruhl K, Stoeter P, Fiumara A, Pavone L, Beck M. Clinical and neuroradiological findings in classic infantile and late-onset globoid-cell leukodystrophy (Krabbe disease). Am J Med Genet. 1996;63(1):209-17.

22. Loonen MC, Van Diggelen OP, Janse HC, Kleijer WJ, Arts WF. Late-onset globoid cell leucodystrophy (Krabbe's disease) Clinical and genetic delineation of two forms and their relation to the early-infantile form. Neuropediatrics. 1985;16(3):137-42.

23. Krivit W. Allogeneic stem cell transplantation for the treatment of lysosomal and peroxisomal metabolic diseases. Springer Semin Immunopathol. 2004;26(1-2):119-32.

24. Phelps M, Aicardi J, Vanier MT. Late onset Krabbe's leukodystrophy: a report of four cases. J Neurol Neurosurg Psychiatry. 1991;54(4):293-6. 
25. Arvidsson J, Hagberg B, Mansson JE, Svennerholm L. Late onset globoid cell leukodystrophy (Krabbe's disease)-Swedish case with 15 years of follow-up. Acta Paediatr. 1995;84(2):218-21.

26. Turazzini M, Beltramello A, Bassi R, Del Colle R, Silvestri M. Adult onset Krabbe's leukodystrophy: a report of 2 cases. Acta Neurol Scand. 1997;96(6):413-15.

27. Verdru P, Lammens M, Dom R, Van Elsen A, Carton H. Globoid cell leukodystrophy: a family with both late-infantile and adult type. Neurology. 1991;41(9):1382-4.

28. Henderson RD, MacMillan JC, Bradfield JM. Adult onset Krabbe disease may mimic motor neurone disease. J Clin Neurosci. 2003;10(5):638-9

29. Debs R, Froissart R, Aubourg P, et al. Krabbe disease in adults: phenotypic and genotypic update from a series of 11 cases and a review. J Inherit Metab Dis. 2013 Sep;36(5):859-68. Epub 2012 Nov 30.

30. Sabatelli M, Quaranta L, Madia F, et al. Peripheral neuropathy with hypomyelinating features in adult-onset Krabbe's disease. Neuromuscul Disord. 2002;12(4):386-91.

31. Grewal RP, Petronas N, Barton NW. Late-onset Globoid Cell Leukodystrophy. J Neurol Neurosurg Psychiatry. 1991;54(11): 1011-12.

32. Lim ZY, Ho AY, Abrahams S, et al. Sustained neurological improvement following reduced-intensity conditioning allogeneic haematopoietic stem cell transplantation for lateonset Krabbe disease. Bone Marrow Transplant. 2008;41(9): $831-2$

33. Schiffmann R, van der Knaap MS. Invited article: an MRI-based approach to the diagnosis of white matter disorders. Neurology. 2009;72(8):750-9.

34. Duffner PK, Granger C, Lyon N, et al. Developmental and functional outcomes in children with a positive newborn screen for Krabbe disease: A pilot study of a phone-based interview surveillance technique. J Pediatr. 2012;161(2):258-63.e1.

35. Puckett RL, Orsini JJ, Pastores GM, et al. Krabbe disease: clinical, biochemical and molecular information on six new patients and successful retrospective diagnosis using stored newborn screening cards. Mol Genet Metab. 2012;105(1):126-31.

36. Wenger DA, Rafi MA, Luzi P, Datto J, Costantino-Ceccarini E. Krabbe disease: genetic aspects and progress toward therapy. Mol Genet Metab. 2000;70(1):1-9.

37. Tappino B, Biancheri R, Mort M, et al. Identification and characterization of 15 novel GALC gene mutations causing Krabbe disease. Hum Mutat. 2010;31(12):E1894-914.

38. Lissens W, Arena A, Seneca S, et al. A single mutation in the GALC gene is responsible for the majority of late onset Krabbe disease patients in the Catania (Sicily, Italy) region. Hum Mutat. 2007; 28(7):742.

39. Husain AM, Altuwaijri M, Aldosari M. Krabbe disease: Neurophysiologic studies and MRI correlations. Neurology. 2004;63(4):617-20.

40. Aldosari M, Altuwaijri M, Husain AM. Brain-stem auditory and visual evoked potentials in children with Krabbe disease. Clin Neurophysiol. 2004;115(7):1653-6.

41. Wang C, Melberg A, Weis J, Mansson JE, Raininko R. The earliest MR imaging and proton MR spectroscopy abnormalities in adult-onset Krabbe disease. Acta Neurol Scand. 2007;116(4): 268-72.

42. De Stefano N, Dotti MT, Mortilla M, et al. Evidence of diffuse brain pathology and unspecific genetic characterization in a patient with an atypical form of adult-onset Krabbe disease. J Neurol. 2000;247(3):226-8.

43. Brockmann K, Dechent P, Wilken B, Rusch O, Frahm J, Hanefeld F. Proton MRS profile of cerebral metabolic abnormalities in Krabbe disease. Neurology. 2003;60(5):819-25.

44. Loes DJ, Peters C, Krivit W. Globoid cell leukodystrophy: distinguishing early-onset from late-onset disease using a brain MR imaging scoring method. AJNR Am J Neuroradiol. 1999; 20(2):316-23.

45. Duffner PK, Barczykowski A, Jalal K, Yan L, Kay DM, Carter RL. Early infantile Krabbe disease: results of the world-wide Krabbe registry. Pediatr Neurol. 2011;45(3):141-8.
46. Tullu MS, Muranjan MN, Kondurkar PP, Bharucha BA. Krabbe disease--clinical profile. Indian Pediatr. 2000;37(9):939-46.

47. Korn-Lubetzki I, Dor-Wollman T, Soffer D, Raas-Rothschild A, Hurvitz H, Nevo Y. Early peripheral nervous system manifestations of infantile Krabbe disease. Pediatr Neurol. 2003; 28(2):115-18

48. Morse LE, Rosman NP. Myoclonic seizures in Krabbe disease: a unique presentation in late-onset type. Pediatr Neurol. 2006;35 (2): 154-7.

49. Duffner PK, Caviness VS, Jr, Erbe RW, et al. The long-term outcomes of pre-symptomatic infants transplanted for Krabbe disease: report of the workshop held on July 11 and 12, 2008, Holiday Valley, New York. Genet Med. 2009;11(6):450-4.

50. Breningstall GN, Patterson RJ. Acquired obstructive hydrocephalus in globoid-cell leukodystrophy. Pediatr Neurol. 2008;39(4): 279-80.

51. Cavanagh N, Kendall B. High density on computed tomography in infantile Krabbe's disease: a case report. Dev Med Child Neurol. 1986;28(6):799-802.

52. Morana G, Biancheri R, Dirocco M, et al. Enhancing cranial nerves and cauda equina: an emerging magnetic resonance imaging pattern in Metachromatic Leukodystrophy and Krabbe disease. Neuropediatrics. 2009;40(6):291-4.

53. Hussain SA, Zimmerman HH, Abdul-Rahman OA, Hussaini SM, Parker CC, Khan M. Optic nerve enlargement in Krabbe disease: a pathophysiologic and clinical perspective. J Child Neurol. 2011;26(5):642-4.

54. Kamate M, Hattiholi V. Normal neuroimaging in early-onset Krabbe disease. Pediatr Neurol. 2011;44(5):374-6.

55. Provenzale JM, Peddi S, Kurtzberg J, Poe MD, Mukundan S, Escolar M. Correlation of neurodevelopmental features and MRI findings in infantile Krabbe's disease. AJR Am J Roentgenol. 2009;192(1):59-65.

56. Barkovich AJ, Raybaud C. Pediatric neuroimaging. Philadelphia, US: Lippincott Williams and Wilkins; 2011.

57. Orsini JJ, Morrissey MA, Slavin LN, et al. Implementation of newborn screening for Krabbe disease: population study and cutoff determination. Clin Biochem. 2009 Jun;42(9):877-84.

58. Li Y, Scott CR, Chamoles NA, et al. Direct multiplex assay of lysosomal enzymes in dried blood spots for newborn screening. Clin Chem. 2004:50(10):1785-96.

59. Wenger DA. Krabbe disease. In: Pagon RA, Bird TC, Dolan CR, Stephens K, editors. GeneReviews. Seattle (WA): University of Washington, Seattle; 1993.

60. Furuya H, Kukita Y, Nagano S, et al. Adult onset Globoid Cell Leukodystrophy (Krabbe disease): analysis of galactosylceramidase cDNA from four Japanese patients. Hum Genet. 1997;100(3-4):450-6.

61. Tokimasa S, Ohta H, Takizawa S, et al. Umbilical cord-blood transplantations from unrelated donors in patients with inherited metabolic diseases: single-institute experience. Pediatr Transplant. 2008;12(6):672-6.

62. Krivit W, Shapiro EG, Peters C, et al. Hematopoietic stem-cell transplantation in globoid-cell leukodystrophy. N Engl J Med. 1998;338(16):1119-26.

63. Lee WC, Kang D, Causevic E, Herdt AR, Eckman EA, Eckman CB. Molecular characterization of mutations that cause globoid cell leukodystrophy and pharmacological rescue using small molecule chemical chaperones. J Neurosci. 2010;30(16): 5489-97.

64. Rafi MA, Rao HZ, Luzi P, Curtis MT, Wenger DA. Extended normal life after AAVrh10-mediated gene therapy in the mouse model of Krabbe disease. Mol Ther. 2012;20(11):2031-42.

65. Neri M, Ricca A, di Girolamo I, et al. Neural stem cell gene therapy ameliorates pathology and function in a mouse model of globoid cell leukodystrophy. Stem Cells. 2011;29(10):1559-71. 